\title{
Research Paper: Health Responses During the COVID-19 Pandemic: An International Strategy and Experience Analysis
}

\author{
Athena Rafieepour $^{1}$ (D), Gholamreza Masoumi ${ }^{2,3,4}$, Arezoo Dehghani ${ }^{5^{*}}$ (D) \\ 1. Department of Occupational Health, Student Research Committee, School of Public Health and Safety, Shahid Beheshti University of Medical \\ Sciences, Tehran, Iran. \\ 2. Department of Health in Emergencies and Disasters, School of Health Management and Information Services, Iran University of Medical Sci- \\ ences, Tehran, Iran. \\ 3. Emergency Management Research Center, Iran University of Medical Sciences, Tehran, Iran. \\ 4. Health in Emergency and Disaster Research Center, University of Social Welfare and Rehabilitation, Tehran, Iran. \\ 5. Department of Health in Emergencies and Disasters, Student Research Committee, School of Public Health and Safety, Shahid-Beheshti University \\ of Medical Sciences, Tehran, Iran.
}

\begin{tabular}{|c|c|}
\hline $\begin{array}{l}\text { Use your device to scan } \\
\text { and read the article online }\end{array}$ & \\
\hline 口ifiring & $\begin{array}{l}\text { ditation Rafieepour A, Masoumi Gh, Dehghani A. Health Responses During the COVID-19 Pandemic: An International Strategy } \\
\text { and Experience. Health in Emergencies and Disasters Quarterly. 2021; 6(3):147-160. http://dx.doi.org/10.32598/hdq.6.3.310.1 }\end{array}$ \\
\hline (1) & dol'http://dx.doi.org/10.32598/hdq.6.3.310.1 \\
\hline
\end{tabular}

\section{(i) (\$)}

Article info:

Received: 12 Nov 2020

Accepted: 10 Feb 2021

Available Online: 01 Apr 2021

\section{Keywords:}

Health, Lessons learned, Disaster management, Pandemic, Covid-19, Health policy

\section{ABSTRACT}

Background: Sharing experiences and learning from health measures taken during the outbreak of epidemics is a critical issue that affects the right and timely decisions in health crises. In the present study, an attempt has been made to review the health policies adopted against COVID-19 and extract critical points for resolving the epidemic crisis.

Materials and Methods: This article was a comparative study. The study population comprised Canada, Japan, Germany, Korea, Turkey, and Iran. Ten effective indicators in the management of epidemics were extracted by reviewing the literature and interviewing disaster management experts, and the degree of conformity of the research community with them was examined. The study data were collected from articles published in scientific databases (Google Scholar, PubMed, Web of Science, and Scopus search engines) or information from COVID-19 disease management organizations from official sites. The obtained data were processed and analyzed by matrix content analysis.

Results: The results showed the importance of 10 effective indicators in the management of epidemics during the outbreak of COVID-19 studied and noticed by the health system of most countries. And the government, local and private organizations have participated in the implementation of the studied indicators according to the conditions of each country's health system. Therefore, the success rate of countries in managing COVID-19 disease varies according to the time, type, and manner of implementation and monitoring of measures.

Conclusion: Speed of action in adopting health policies and integration in its implementation, construction of convalescence, adequate training and access to personal protective equipment, prevention of nosocomial contamination, and voluntary assistance are essential issues in the fight against epidemics. These measures should be considered and used as teachings in managing health crises, especially emerging diseases and pandemics.

\footnotetext{
* Corresponding Author:

Arezoo Dehghani, PhD.

Address: Department of Health in Emergencies and Disasters, Student Research Committee, School of Public Health and Safety, Shahid-Beheshti University of Medical Sciences, Tehran, Iran.

E-mail: dehghani.am64@gmail.com
} 


\section{Introduction}

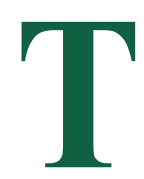

he COVID-19 was first detected in December 2019 in Wuhan, China. The virus caused a type of viral pneumonia with the ability to spread rapidly from person to person, which is due to the characteristics of its genome structure. It was classified as Acute Respiratory Syndrome (SARS-2002) and the Middle East Respiratory Syndrome (MERS-2012) [1,2].

The COVID-19 spread rapidly worldwide and was identified by the WHO as a significant public health concern [3] as of September 15, 2020, 12:02 GMT. It has infected 29475633 people in 215 countries, of whom 933444 died [4]. The death rate from the COVID-19 in most countries was estimated at $3.61 \%$ [5], which was more prevalent among the elderly or those with underlying diseases such as diabetes, cardiovascular disease, chronic respiratory disease, blood pressure, and cancer [1].

Over time, examining hospitalized cases showed that children and younger people are also more likely to be infected with the COVID-19 [6, 7]. Furthermore, involvement of the kidneys and other organs in patients with the COVID-19 has also been reported by some researchers [8]. In addition, the cardiovascular system in patients with COVID-19 is severely affected by the virus or drug treatments, and as a result, the mortality rate due to cardiac arrest has increased during the outbreak of the disease [9]. Therefore, efforts to control the disease and prevent its spread are on the agenda of governments; thus, several measures have been taken.

Efforts to reduce the disease transmission have been significantly effective with taken measures such as quarantine, reduction of displacement, increasing social distance, and strict adherence to basic hygiene principles $[10,11]$. However, the rapid spread of COVID-19 infection is associated with fundamental changes in the health care system [12]. The high cost of caring for people with COVID-19, the provision of beds, ventilators, and concerns about staff health and personal protective equipment have posed challenges to each country's health and economic system [13].

Many countries take measures such as building new hospitals (China) [1], designing and using a patient tracking application (Singapore) [14], designing and operating a corona screening system (Iran) [15], and implementing quarantine operations along with increasing the capacity of the hospitals (Italy) [16] to minimize the challenges of the treatment system. In addition, new vaccines were designed and tested for the COVID-19 in various countries worldwide [17]. But what is important here is to share successful experiences fighting the virus to disrupt the epidemic chain as soon as possible.

Hick and Biddinger argued that countries should not act as an island in the face of epidemics and pandemics and should take steps to prevent the spread of disease by sharing health data [18]. However, learning from the measures taken in different countries is a relatively new subject that can effectively achieve the right policy to deal with future epidemics. In 2015, the World Health Organization (WHO) launched the Global Learning Laboratory (GLL) to be used as a space for sharing lessons and tools focused on Universal Health Coverage [19]. Therefore, in this article, we decided to review the measures taken in selected countries to combat the COVID-19 and analyze international policies and experiences to develop appropriate health guidelines to deal with the inevitable health threats of the future.

\section{Materials and Methods}

A comparative study method was used to evaluate and explain the experiences of COVID-19 disease management in selected countries of the world. The study population includes Canada, Japan, Germany, Korea, Turkey, and Iran, which are not only among the leading countries in the management of COVID-19 disease but also have been affected mainly by this disease. In selecting these countries, we attempted to study at least one country from each continent. Initially, 10 effective indicators in the management of COVID-19 epidemic disease were extracted using literature review and interviews with professors and epidemiology management experts. Then, the outcome of the indicators was done to extract the differences and similarities between health systems strategies in different countries. Thus, the differences and similarities between different countries were compared and applied in the next step.

The study data were collected from articles published in scientific databases (Google Scholar, PubMed, Web of Science, and Scopus databases) or online reports of government agencies or COVID-19 disease management bodies and based on specified search strategies. The data from each country were collected based on the indicators of current research in the management of COVID-19 and were written separately for each country. The inclusion criteria were experiences based on defined indicators and access to information, and exclusion criteria were complete lack of access to information or information in languages other than English and Persian. 
The matrix content analysis method was used to analyze the obtained data. In this method, content analysis was conducted with indicators, and the models obtained from the studies were placed in the designed matrix. Finally, the extracted indices were analyzed.

\section{Results}

\section{Germany}

Germany, with more than 83 million population (September 15, 2020, 12:34 GMT), with 263407 infected, 9437 dead, and 237550 recovered, ranked 22nd in the world in terms of COVID-19, and only $1 \%$ of their patients have been reported in critical condition [20]. Germany responded to the COVID-19 outbreak by implementing a national program at the federal level by the Robert Koch Institute (RKI). The low rate of fatalities versus the high rate of infected patients indicates the successful policies of the country's health system, which includes rapid measures such as a large number of screening tests (500000 tests per week), rapid implementation of social prevention methods, high bed-to-patient ratio (56000 beds for people with coronary artery disease), $€$ three billion budget allocation to 1000-bed hospital by the German army and forced to wear a mask. Other practical measures of the German health system included initial contact with a family doctor or 115 emergencies and providing medical information, if necessary, initial examination and quarantine of the patient at home or hospitalization, and use of innovative facilities of drive-through testing.

Iran

A country with more than 84 million population (September 15, 2020, 12:34 GMT) is ranked 12th globally in terms of COVID-19 disease, with 407353 infected, 23453 dead, 349984 recovered, and 11\% have reported comorbid malignancies [20]. Iran, by creating the National Headquarters for Corona, took health-oriented decisions in various areas of the country, and by stopping unnecessary services in hospitals (selective surgeries) and allocating IRR 1000 billion budget for the credit of the treatment system in the first phase be ready, as well as increasing the capacity of hospitals to provide services, took adequate steps to combat the spread of the disease. On the other hand, measures such as screening at the entrances of cities by Red Crescent volunteer forces, minimizing hospital visits, setting up a telemedicine system to care for patients and necessary treatment measures, plasma therapy, appointing a spokesperson for the National Corona Management Headquarters, launching Hot Line 4030, to answer frequent questions about the corona, launched the Corona Disease Self-Assessment System, developed and launched the Tuck application (nutrition, safety, and corona) to diagnose the disease in the shortest possible time.

Turkey

Turkey, with more than 84 million population, was ranked 19th in the world for COVID-19 on September 15, 2020, at 12:34 GMT. To date, 292878 people have been infected, 7119 have died, and 260058 have recovered [20]. Despite the similarity between Turkey's population and cultural structure with Iran, the overall number of patients with this disease is less reported than in Iran [20]. Observing social distance and banning traffic in the city and canceling all scientific, cultural, artistic, and sports events in the country, and starting online education in schools and universities have been among the measures taken by Turkey to manage this disease.

Japan

Japan, with a population of 126 million (as of September 15, 2020, 12:34 GMT), is ranked 44th globally regarding the number of people with COVID-19, with 75657 infected 1442 dead, 67242 recovered, and 2\% have reported comorbid malignancies. However, Japan has a minimal number of patients whose reasons can be attributed to the proper functioning of the government and the country's health system, including the early cancellation of all cultural, social, political, sports, and artistic events, the closure of educational centers, the production of diagnostic equipment and its pilot use at airports. In addition, for short-term quarantine of incoming passengers from infected areas, a new test method was implemented to speed up the detection of COVID-19 in 30 minutes by the State Research Institute. Also, the country established a policy to protect against the spread of the coronavirus, such as asking people with mild symptoms to stay home until they recover and asking companies to promote telecommuting and variable opening hours.

\section{Italy}

With more than 60 million people (September 15, 2020, 12:34 GMT), Italy reported about 288761 infected, 35624 deaths, and 213950 cases recovered. At the time of the study, it was ranked 20th regarding COVID-19 disease globally [20]. The most crucial action of the Italian health system in the face of COVID-19 disease was using local health authorities in developing health instructions appropriate for each region. Also, the 
closure of religious places and the use of virtual medicine in providing services to patients to prevent congestion in medical centers was another effective measure in this country.

\section{South Korea}

Using the lessons learned from the 2015 MERS outbreak, South Korea could (on September 15, 2020, 12:48 GMT) become 77th in the world with a population of more than 51 million, due to the infection of 22391 people and the death of 367 people and the recovery of 18878 people from COVID-19 disease [20]. Furthermore, the country enhanced its capacity to monitor and deal with the rapid adoption of laws and developing a comprehensive framework for dealing with infectious diseases. Also, it established specialized departments for risk assessment, emergency operations, crisis communication, and increasing the capacity of hospitals to prevent and control infectious diseases to manage this disease very well.

South Korea has begun operations with 532 treatment centers for people infected with the COVID-19. As a result, it has the highest rate of COVID-19 testing in the world. On the other hand, hospitals conducted remote diagnostics for patients with mild symptoms and helped medical professionals to focus on people with more severe symptoms. They created a smartphone app to warn mobile users of places where people are infected and provide the possibility of announcing the health conditions of people with the authorities. These measures were taken to detect the disease at its early stage. In addition, a five-division system was developed to allow the general use of the mask, allowing each person to purchase two masks per person during the working days of each week, determined by the last digit of each person's year of birth. And if they do not buy the mask on the specified days, they can buy their quota on the weekend of the same week.

\section{Discussion}

The prevalence of COVID-19 in 215 countries worldwide has prompted governments to develop national strategies tailored to their social, political, economic, cultural, and religious conditions and adhere to international strategies and implement them to manage this disease optimally. Considering the type of crisis, the necessary actions of any government are in health system services management, which can help improve the current challenging conditions of societies by slowing down the epidemic process. In this regard, in this study, 10 essential health measures indexes to manage the COVID-19 crisis in 6 countries were compared. The results showed that some health management programs could be effective in reducing morbidity and mortality. Furthermore, learning from successful global strategies and customizing them can strengthen countries' preparedness for the inevitable crises ahead.

The World Health Organization (WHO) recommends that the efforts and programs of all countries involved in the corona crisis be reviewed and its results used to strengthen the health system [76]. However, studies show that countries do not use other countries' lessons learned and experiences. A workshop after the influenza pandemic organized by the WHO in 2005 with the participation of the European Center for Disease Control and Prevention emphasized that the development and revision of pandemic preparedness programs should be facilitated by the transfer of information and best practices from other countries and all countries should share these experiences. Using this lesson also helps other healththreatening situations and enables International Health Regulation (IHR) [77].

Successful pandemic management systems include the Thai Ministry of Health, which, using the experience of Australia, Hong Kong, and China, has been able to improve its programs in influenza pandemic management (2009) [78]. Awareness of what has been learned helps countries be prepared to deal with other emergencies threatening health. The Chinese government has improved its capacity to respond to epidemics since 2003, following the SARS outbreak and addressing its challenges. This experience helped China successfully manage COVID-19 despite its initial emergence [79], demonstrating the importance of using the lessons learned in epidemics and disasters.

Following the outbreak of COVID-19, the WHO declared a state of emergency and set up an international committee of 15 members, urging countries with poor health to respond quickly to the disease and take effective measures in its proper management according to the local conditions [76].

The review of management measures in the present study also showed that most of the prosperous countries in the field of the COVID-19 crisis had taken steps to establish a National Corona Countermeasures Headquarters in the very first days of the epidemic, in addition to optimal policy in the field of health measures. They intended to have adequate supervision over the proper implementation of these guidelines (Tables 1 and 2). The 
Table 1. Health strategies of selected countries in 10 research indicators in Covid-19

Index $/ \begin{array}{cc}\text { Establishment } \\ \text { of the National } \\ \text { Headquarters } \\ \text { Against COVID-19 }\end{array} \quad \begin{gathered}\text { Setting up a Conva- } \\ \text { lescent Home }\end{gathered}$

Since the coronavirus outbreak in Germany, the federal government of the Robert Koch Institute has set up coronation headquarters [21].
On May 11, 2020, a convalescent home with a capacity of 160 patients and an oxygen supply system with a capacity of $14000 \mathrm{~L}$ were set up at an air military center [22]

\section{Allocation of Hos- pitals to COVID-19 Patients \\ Import and Export of Masks, Gowns, and Shields}

To provide adequate access to medical services, all hospitals were required to provide services to COVID-19 patients [23].
The COVID-19 Disease Management Group was set up supervised by the President to formulate the necessary health, economy, and society policies based on the existing conditions [25] A scientific committee was also set up at the General Medical Emergency Operations Center at the Ministry of Health [26].

The Japanese government complied with its state of emergency law, according to which the head of each state and city will make policies and decisions based on the circumstances [31].

The COVID-19 National Committee was established following a presidential decree and chaired by the Minister of Health. In addition, COVID-19 provincial committees were formed under the governor's direction, and a secretariat was set up under the presidents of the country's medical universities [36].

Treatment Costs of COVID-19 Patients

On March 4, 2020, a general decree banned all personal protective equipment from Germany. Following control of the disease, the sentence was overturned on March 19, 2020.

Exporting companies were required to obtain a special permit from the government to send their products [24].

Export license for CPR equipment, ventilation equipment, oxygen generator, piping, intensive

In May 2020, a new hospital with 600 beds and 99

On April 6, 2020, a 1000-bed convales cent home was set up by the Presiden at Istanbul's Ataturk

Airport [27]

intensive care beds was opened to provide services to COVID-19 patients, dedicated solely to hospitalization and medical services for these patients [28] care equipment, chlorine, disinfectant, filter masks, surgical masks, sterile gloves, clothing, and goggles under the Agency's Personal Protection Equipment Regulations Turkish medicines and medical devices are obtained. Also, the customs fee for importing this equipment was eliminated [29].

Patients with mild symptoms were referred to COVID-19 hotels and temporary accommodation to prevent unnecessary hospital beds occupation and waste of financial and human resources [32]
More than 27000 convalescent beds were set up in hotels, crisis management shelters, and exhibition and commercial spaces across the country. In addition 3000 hospital beds were created at the Iran Mall Exhibition Center to receive patients with $\mathrm{CO}$ VID-19.
St. Luke's International Hospital was introduced as the primary hospital for the admission of COVID-19 patients. Outpatients were screened at all hospitals [33].
Armed Forces hospitals announced emergency admission readiness for COVID-19 patients, and the Army Headquarters established a 2000bed hospital. In addition, 22 corona clinics were established in Tehran to facilitate work and prevent overcrowding.
The export and import of masks and disinfectants were banned for two months, during which time the government banned the international sale of surgical masks while providing financial assistance to mask manufacturers [34].

A memorandum of cooperation was signed in the field of production of protective fabrics for medical personne in cooperation with the Ministry of Health, Treatment and Medical Education, Ministry of Industry, Mines and Trade, National Medical Equipment Office, Iranian Textile and Garment Production and Export Union and 4000 daily Protective clothing was produced for health system staff.
In addition to German citizens, not all European patients in Germany paid for COVID-19 treatment in hospitals. In addition, health insurance was provided for international students, and the cost of treatment for COVID-19 became free [10].

As of April 16, 2020 all medical and pharmaceutical expense of patients with COVID-19 in Turkish public hospitals were covered by insurance by the President and became accessible for patients [30].

Japan National Health Insurance covered the cost of a corona diagnosis

[34]. COVID-19 patients admitted to hospitals are exempt from paying $10 \%$ to $30 \%$ of hospital costs [35].

They were providing free health care services to COVID-19 patients with positive laboratory results. In addition, donors covered part of the cost of treatment. 


\begin{tabular}{|c|c|c|c|c|c|}
\hline Index & $\begin{array}{l}\text { Establishment of the } \\
\text { National Head- } \\
\text { quarters Against } \\
\text { COVID-19 }\end{array}$ & $\begin{array}{l}\text { Setting up a Con- } \\
\text { valescent Home }\end{array}$ & $\begin{array}{l}\text { Allocation of a Hos- } \\
\text { pital to COVID-19 } \\
\text { Patients }\end{array}$ & $\begin{array}{l}\text { Import and Export } \\
\text { of Masks, Gowns, } \\
\text { and Shields }\end{array}$ & $\begin{array}{l}\text { Treatment Costs of } \\
\text { COVID-19 Patients }\end{array}$ \\
\hline
\end{tabular}

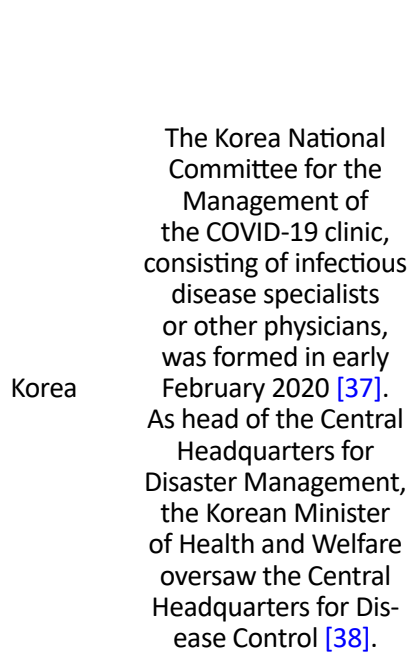

People with mild symptoms were admitted to government-supervised convalescent homes and dormitories [39, 40].

According to a South Korean government decree, hospitals among public and private treatment centers were only dedicated to admitting patients with COVID-19, which were equipped with isolation chambers with negative pressure and a suitable distance between beds. Other hospitals also accepted patients with milder symptoms. A total of 67 hospitals with 7000 beds were dedicated to receiving patients with COVID-19 nationwide [41].

Continuous intensive care units were also set up to help provide medical care at home. Providing medical and care services at home and training family members to care for patients in acute cases were used. Home care services were also provided for the elderly, the disabled, and patients after discharge from the hospital. Some hote rooms were also reserved for people with quarantine restrictions [46].
The number of masks available in pharmacies was measured [42]. The supply of health products and equipment such as clothing for medical teams also increased

[43]. According to

the South Korean

Ministry of Economy and Finance, about 8 million domestically produced face masks were distributed

directly to the genera public. The government also called for increased mask production to 10 million a day and a ban on its export [43]. personal protective masks and protective

The Korean government used cost-effective tests to diagnose COVID-19, which received a government subsidy. It also used innovative features of drive-through testing [44]. In addition, the government was responsible for providing treatment grants, and the Korean

government covered all costs of diagnosis and treatment fol-

lowing the Infectious Diseases Prevention Act [45].

On January 31, 2020 the Italian government appointed a person to head the Department of Civil Protection, responsible for providing personal protective equipment and delivering it to local health authorities [48]. Many textile industries produced masks during the holidays. The government also began importing masks from reputable brands approved by health institutions and legalized themselves with mask hoarders [49].
Italy's health care system covers treatment costs through national and regional

taxes under the Global Coverage Protocol. The public sector accounts for $78.2 \%$ of total health care costs, and local governments are responsible for providing health care.

For patients with COVID-19, similar government services were used to help which is often free [50]. pay for treatment,

\section{Hlealth in}

Emergencies and |D]isasters [Oluarterly

National Corona Headquarters were set up in Korea and Germany with the lowest number of infected and dead people in a health research center attended by scientists in disease management [21]. This experience shows that the presence of health professionals can be effective in the success of strategies adopted in the management of a disease.

According to the WHO, one of the most important measures in the management of COVID-19 disease is the early diagnosis and screening of this disease. By ac- tivating the maximum laboratory capacity, Korea could achieve a special place in the success of COVID-19 management [76]. A review of country documents shows that KCDC (Korea Centers for Disease Control and Prevention) in Korea has used emergency methods to track tests quickly. They performed 18000 diagnostic tests per day, used innovative drive-through testing in disease screening, and encouraged people to take the test to prevent the spread of disease [80]. In addition, awareness of contaminated areas through the design and use of a traffic routing application for infected people in Korea 
Table 2. Health strategies of selected countries in 10 research indicators in Covid-19

\begin{tabular}{|c|c|c|c|c|c|}
\hline Country & $\begin{array}{l}\text { Employing Volun- } \\
\text { teers in Hospitals }\end{array}$ & $\begin{array}{c}\text { Hospital Infection } \\
\text { Control }\end{array}$ & $\begin{array}{l}\text { Providing } \\
\text { Resources and } \\
\text { Credits in the } \\
\text { Field of Health }\end{array}$ & $\begin{array}{l}\text { Communication and } \\
\text { Information (Inter- } \\
\text { national / National / } \\
\text { Social Media Use) }\end{array}$ & $\begin{array}{c}\text { Teach Employees } \\
\text { the Principles of } \\
\text { Personal Hygiene } \\
\text { and PPE }\end{array}$ \\
\hline
\end{tabular}

Volunteers in the management of COVID-19 at the hospital included medical students who assisted physicians and nurses as assistants [51]. A

Germany group of volunteers also provided primary health care and psychological support in person or online to quarantine patients at home and in convalescent homes [51].

\begin{tabular}{|c|c|c|}
\hline Turkey & $\begin{array}{l}\text { Due to the } \\
\text { high number } \\
\text { of hospitalized } \\
\text { patients, volunteer } \\
\text { forces were used in } \\
\text { COVID-19 general } \\
\text { wards. However, } \\
\text { in certain sections, } \\
\text { such as the } \\
\text { children's section, } \\
\text { volunteers were } \\
\text { banned from enter- } \\
\text { ing [56]. }\end{array}$ & $\begin{array}{l}\text { In addition to medical } \\
\text { supplies, employees } \\
\text { should take disinfec- } \\
\text { tants and clean their } \\
\text { personal belongings to } \\
\text { the workplace, such as } \\
\text { cell phones, keyboards, } \\
\text { landlines, keys, tables, } \\
\text { chair handles, stair rail- } \\
\text { ings, elevator buttons, } \\
\text { handles, and door } \\
\text { handles. The process } \\
\text { of rapid reporting of } \\
\text { symptoms in staff was } \\
\text { defined and informed } \\
\text { [57]. Adequate personal } \\
\text { protective equipment } \\
\text { was provided to staff. } \\
\text { Disposal of infectious } \\
\text { wastes of patients and } \\
\text { gowns and masks was } \\
\text { done completely sepa- } \\
\text { rately [58]. }\end{array}$ \\
\hline Japan & $\begin{array}{l}\text { Medical and } \\
\text { nursing students } \\
\text { and retirees were } \\
\text { recruited to volun- } \\
\text { teer at the hospital } \\
\text { [62]. }\end{array}$ & $\begin{array}{l}\text { Patients with or even } \\
\text { suspected of COVID-19 } \\
\text { were admitted to a } \\
\text { separate room [63]. } \\
\text { To reduce the hospital } \\
\text { staff's exposure to } \\
\text { patients, a robot was } \\
\text { used to deliver food and } \\
\text { medicine to patients' } \\
\text { rooms [64]. Screening } \\
\text { measures were per- } \\
\text { formed upon the arrival } \\
\text { of patients to the hospi- } \\
\text { tals [65]. Treatment staff } \\
\text { were required to use } \\
\text { all personal protective } \\
\text { equipment and were } \\
\text { periodically tested for }\end{array}$ \\
\hline
\end{tabular}

Patients with COVID-19 were admitted to provided services by trained personnel. Both the patient and the service providers used complete personal protective equipment.

Family visits were restricted. The disinfectant was used to disinfect the surfaces. The surfaces of the patient's room were disinfected twice a day, and the infectious waste was disposed of separately [52] tants and clean their personal belongings to the workplace, such as cell phones, keyboards, chair handles, stair railings, elevator buttons, handles, and doo handles. The process of rapid reporting of defined and informed

[57]. Adequate persona Disposal of infectious wastes of patients and gowns and masks was rately [58] isolated rooms and
Public and social media were used for education to increase public awareness of the danger Social messaging taught information about health practices and ways to dea with the disease. Due to the presence of German citizens in other countries, international networks were used to inform about the status of the disease and travel restrictions [54].
Personal hygiene and PPE training is part of the annual training of hospital staff, but in this epidemic, as soon as China first reported, training was again held in workshops and training videos for all hospital staff [55].
In 2020, \$ 8.4 billion was allocated to the Ministry of Health, which was the largest share of the budget to combat the corona pandemic [59].
A clear, transparent, and up-to-date information strategy was developed to increase public awareness of COVID-19 risk and public confidence. All information channels were used to increase the speed and dissemination of news in the community. Virtual networks were constantly monitored to address ethical issues and prevent the spread of rumors. Most international interviews were conducted by the President of Turkey based on official country data [60].
Because of the high severity and speed of the spread of COVID-19 disease, an intensive course on using personal protective equipment and the principles of proper handwashing and disinfection of surfaces was held for various hospital staff, and educational clips were also provided to them as retraining [61].
An emergency budget of $\$ 100$ million was allocated to control the virus and $\$ 2$ billion to combat the COVID-19 [34].
Minimal information was provided on COVID-19 to reduce public fear. Because of careful monitoring of published content, some unofficial sites were filtered [66]. Doctors and nurses were banned from interviewing the media [32].
Simulation exercises to teach the principles of personal hygiene and PPE were given to staff in different departments of COVID-19 treatment [67]. 


\begin{tabular}{|c|c|c|c|c|c|}
\hline Country & $\begin{array}{l}\text { Employing Volun- } \\
\text { teers in Hospitals }\end{array}$ & $\begin{array}{c}\text { Hospital Infection } \\
\text { Control }\end{array}$ & $\begin{array}{l}\text { Providing } \\
\text { Resources and } \\
\text { Credits in the } \\
\text { Field of Health }\end{array}$ & $\begin{array}{l}\text { Communication and } \\
\text { Information (Inter- } \\
\text { national / National / } \\
\text { Social Media Use) }\end{array}$ & $\begin{array}{c}\text { Teach Employees } \\
\text { the Principles of } \\
\text { Personal Hygiene } \\
\text { and PPE }\end{array}$ \\
\hline
\end{tabular}

A voluntary registration system for the management and control of the coronavirus and a system of direct communication between nurses or assistant nurses were set up by the Ministry of Health. In addition, volunteer physicians and paramedics were also dispatched to specific areas for COVID-19 control and treatment.

General practitioners were trained and assisted by active physicians to fulfill their commitment to work in the days of the corona outbreak

[44, 45]. About 150

Korea physicians from the Daegu Medical Association volunteered to visit quarantine patients at home [37].

Volunteers were also registered to use their services in case of emergency [38].
Scientific and safe methods isolated hospital waste related to COVID-19 patients and then delivered it to special municipal systems [36]. Maintaining a distance of one meter between patients and doctors in medical centers, preventing congestion by using telephone or Internet appointments and receiving fees electronically, as well as providing masks and gloves to suspicious patients, improving ventilation and disinfection of surfaces with appropriate disinfectants approved by the Food and Drug Administration was continuously and correctly on the agenda of the Ministry of Health to hospitals [68].

The Financial and Budget Assessment Group was formed within the COVID-19 National Committee, and a Memorandum of Understanding was signed between the Foreign

Exchange Board of the Ministry of Health, the Food and Drug Administration, and the Ministry of Defense to expedite the supply of COVID-19 equipment. -

The national campaign, entitled "We Defeat the Corona" and "I Wear a Mask", was organized by the National Committee and was reported at the national media level. A working group was formed to provide accurate information and training to individuals, whose duties include educating and informing about the new coronavirus under the supervision of provincial medical universities. The Ministry of Health also sent educational messages to all citizens across the country. The official COVID-19 statistics were provided by the official spokesperson of the Ministry of Health at the national media level or related social media pages, and the information of the COVID-19 National Epidemiology Committee at the Ministry of Health was set up to announce daily trends and epidemiological models of the disease nationally and globally. In addition, educational billboards were installed in many cities.

Corona mapping with the ability to present contaminated areas and people suspected of COVID-19 was done via GPS and smart cards and was made available to the public to prevent crowding in contaminated

The South Ko-

Hospital waste related to COVID-19 patients was isolated by scientific and safe methods and then delivered to special municipal systems [36]. rean government funded COVID-19 testing, medical treatment, and patients' living expenses from the state budget [69].

\section{areas. In addition, accu-} rate statistics of infected people, deaths, and recovered were provided to patients on the official website of the Korea Center for Disease Control and Prevention and online news on the popular website and social media attributed to the government [70]. The "Social Distance" campaign was launched on March 22 in Seoul, just 12 days after the first infection was diagnosed [71]
Personal hygiene protocols against coronavirus were developed, and "Guidelines for the proper use of COVID-19 personal protective equipment for outpatient centers" as well as "Environmental Control Guidelines for Combating COVID-19" were published.
The Korean government has ordered training on caring for patients with COVID-19, which includes taking a diagnostic test, treating infectious diseases, and wearing protective clothing [44, 45]. 


\begin{tabular}{|c|c|c|c|c|c|}
\hline Index & $\begin{array}{l}\text { Employing Volun- } \\
\text { teers in Hospitals }\end{array}$ & $\begin{array}{c}\text { Hospital Infection } \\
\text { Control }\end{array}$ & $\begin{array}{l}\text { Providing } \\
\text { Resources and } \\
\text { Credits in the } \\
\text { Field of Health }\end{array}$ & $\begin{array}{l}\text { Communication and } \\
\text { Information (Inter- } \\
\text { national / National / } \\
\text { Social Media Use) }\end{array}$ & $\begin{array}{c}\text { Teach Employees } \\
\text { the Principles of } \\
\text { Personal Hygiene } \\
\text { and PPE }\end{array}$ \\
\hline Italy & $\begin{array}{l}\text { On social media, } \\
\text { private volunteer } \\
\text { groups were } \\
\text { formed for financial } \\
\text { and emotional } \\
\text { support. Volun- } \\
\text { tary campaigns } \\
\text { were launched in } \\
\text { Milan, with the } \\
\text { help of the people } \\
\text { and the mayor } \\
\text { of the region, to } \\
\text { provide medicine } \\
\text { and services to } \\
\text { people affected by } \\
\text { COVID-19. Priests } \\
\text { and students } \\
\text { volunteered. Some } \\
\text { doctors and nurses } \\
\text { also volunteered to } \\
\text { be sent to infected } \\
\text { areas [72]. }\end{array}$ & $\begin{array}{l}\text { To control nosocomial } \\
\text { infections and prevent } \\
\text { the spread of the } \\
\text { disease, the movement } \\
\text { of people from areas } \\
\text { equipped with diagnos- } \\
\text { tic test sites was made } \\
\text { possible to prevent the } \\
\text { spread of the disease by } \\
\text { early monitoring [40]. }\end{array}$ & $\begin{array}{l}\text { Treatment costs } \\
\text { were covered } \\
\text { by national and } \\
\text { regional taxes, } \\
\text { which account } \\
\text { for } 78.2 \% \text { of } \\
\text { total health } \\
\text { care costs. Local } \\
\text { governments are } \\
\text { responsible for } \\
\text { providing health } \\
\text { care. Patients } \\
\text { with COVID-19 } \\
\text { also used govern- } \\
\text { ment services } \\
\text { similar to those } \\
\text { previously used } \\
\text { to help pay for } \\
\text { treatment, which } \\
\text { in most cases was } \\
\text { free [42]. }\end{array}$ & $\begin{array}{l}\text { In some areas, the mayor } \\
\text { personally attended public } \\
\text { places and invited people } \\
\text { to stay at home. Social } \\
\text { media was also used to } \\
\text { encourage people to stay } \\
\text { home [73]. For example, } \\
\text { the \# fermiamoloinsieme } \\
\text { campaign on social media } \\
\text { was launched to invite } \\
\text { people to quarantine } \\
\text { at home. In addition, } \\
\text { information on COVID-19 } \\
\text { statistics and news was } \\
\text { provided in the Italian } \\
\text { national media and inter- } \\
\text { nationally [74]. }\end{array}$ & $\begin{array}{l}\text { The correct } \\
\text { method of using } \\
\text { personal protec- } \\
\text { tive equipment } \\
\text { was taught to the } \\
\text { medical staff by } \\
\text { the local health } \\
\text { authorities [75]. }\end{array}$ \\
\hline
\end{tabular}

is another successful experiment in reducing the spread of the disease that can be localized and used by other countries [70].

Other essential measures in the management of COVID-19 disease were the protection of medical personnel and the prevention of the financial and workload of hospitals [81]. One successful strategy for controlling the health care wave is "forward triage" or patient classification before entering the emergency department. Remote diagnosis and treatment or virtual medicine is another method that effectively screened the disease or applied home quarantine while maintaining the health of the patient and the treatment staff [82]. Italy has taken appropriate measures to screen patients and reduce unnecessary referrals to medical centers using telemedicine [83]. Keeping people away from significant sources of infection, such as hospitals and providing services at home, is another effective measure that can reduce the incidence of the disease. Therefore, having similar technologies in other countries is recommended to deal with the spread of epidemics.

Protecting the health of medical staff against infectious diseases is another issue that can help meet the challenge of reducing the number of specialists in disease control. Protecting the health of medical staff is an essential issue that the WHO also addressed its importance as a prerequisite for patient safety in the slogan of the World Patient Safety Day on September 17, 2020 [84]. In this regard, personal protective equipment and training on how to use it properly can help reduce the risk of infection to a great extent. However, studies show that only $15 \%$ of physicians have received complete and sufficient training to use personal protective equipment [85]. Early in the outbreak of COVID-19, in some countries, such as Italy, there were problems with the supply of medical equipment, in which a large number of medical staff were infected and required to use personal protective equipment by local health authorities. However, the disagreement of some famous Italian leaders over the requirement to use personal equipment created some problems [86, 87].

In Iran, by concluding memoranda of understanding with the textile industry and knowledge-based companies, extensive measures have been taken in the production of personal protective equipment, and with the increase in production capacity, activities were carried out in the field of limited export of personal protective equipment to some countries in the crisis of shortage of this equipment. Also, effective measures were taken at the national level to teach the correct method of using personal protective equipment, and similar measures were taken in other countries studied in this study. Furthermore, utilizing existing potentials to increase the production capacity of equipment needed to deal with a crisis and cross-sectoral cooperation and procedural unity is another practical factor that can effectively reduce constraints. 
According to WHO, the convents with three main features (rapid construction, large-scale, and low cost) and five essential functions of quarantine (triage, primary medical care, frequent and rapid monitoring, and providing social services) to implement the predominant strategy will be very effective to cope with the COVID-19 crisis [42]. Thus, many advanced countries have set up convalescent homes in field hospitals, nursing centers, or allocation of hotels, airports, and other public centers to temporary care centers, or, like Italy, they have benefited from home quarantine and telemedicine services. Moreover, managing patients with contagious infections and providing timely medical services until a complete cure can effectively prevent the spread of the disease can be considered in the management of subsequent crises.

With the daily increase in the number of patients with COVID-19 disease and the illness of medical staff, the capacity to provide services in hospitals decreased, so no guidelines and instructions were provided to establish a dedicated hospital. On the other hand, this measure is not cost-effective and is less effective because there is contamination in all medical centers due to the presence of asymptomatic carriers [88]. But China and Italy built a specialized hospital, and Iran evacuated some of its hospitals and turned it into a dedicated hospital for COVID-19 patients, which returned to its original condition after two weeks due to ineffectiveness. COVID-19 disease, as a long-standing pandemic, has many economic dimensions and poses a significant threat to the achievement of the United Nations Sustainable Development Goals (SDGs). One of the goals of sustainable development is fair and universal access to health services [89].

The study showed that all countries have paid for the diagnosis and treatment of COVID-19 through insurance coverage or the services of government agencies, sponsors, and donors. Having the same health services for people with different economic backgrounds is an effective way to control epidemic diseases that can effectively manage health crises.

The COVID-19 disease has a wide range of dimensions and effects, the most important of which is to increase the burden of hospital services and the disease of medical staff. Volunteers can be a good help in managing hospital services [90]. Because most hospitals need expert personnel familiar with medical sciences, most countries in this study invited the nursing and medical volunteers, retired medical staff, and students to provide support services in the field of treatment or to provide educational, health, and screening services in the field of health. The use of volunteers and the invitation of health retirees is an effective measure to reduce the service load of the treatment system, which can be considered an efficient process in emergencies of epidemics.

The diverse outcomes of COVID-19 required different indices to evaluate health system. This study only reviewed 10 indicators of the response phase of the COVID-19 crisis, which is one of the limitations of this study. Also, the selection of countries according to the authors' nationality, the country's success in health and disease management, and the availability of information in Persian or English are other limitations of this study and require further research.

\section{Conclusion}

A pandemic of viral diseases such as COVID-19 is one of the world's challenges at various intervals. Because of emerging diseases, epidemics, and pandemics worldwide, it is necessary to use the lessons learned to manage these diseases. In epidemics, prevention is an essential step because the disease is emerging, and treatment is impossible in the first weeks and months of the outbreak.

Therefore, training and employing health personnel to promote culture and public health literacy are among the measures that can effectively control diseases. Disseminating the teachings of these events and using them for education in schools and the general public can reduce the severity of unavoidable future events. Establishing infectious disease centers and using their knowledge, scientific and skill capacity in disease management is another factor that will lead to a unified procedure in formulating and implementing preventive laws away from political issues and is therefore essential. Also, implementing new technological and electronic facilities during all phases of crisis management of infectious diseases, such as risk reduction (education), preparedness, response, rehabilitation, and recovery, can control this disease more effectively. It is consistent with new and widely used methods of obtaining information. Prompt action to control an epidemic is like preventing a fire from spreading to nearby buildings, thus preventing the spread of the disease. Therefore, it is recommended that countries act honestly (away from political disputes) in presenting their strengths and weaknesses in providing health services and establish a unified system for learning from experiences gained to provide valuable and practical guidelines for dealing with subsequent crises. 


\section{Ethical Considerations}

\section{Compliance with ethical guidelines}

This article was approved by the Vice-Chancellor of the Iran University of Medical Sciences (Code: IR.IUMS. REC.1400.087)

\section{Funding}

This research was supported by the Iran University of Medical Sciences (Research Project: 087).

\section{Authors' contributions}

All authors equally contributed to preparing this article.

\section{Conflict of interest}

The authors declared no conflict of interest.

\section{Acknowledgments}

The authors would like to thank the Vice-Chancellor for Research of the Iran University of Medical Sciences for approving the research project.

\section{Reference}

[1] Wu Z, McGoogan JM. Characteristics of and important lessons from the coronavirus disease 2019 (COVID-19) outbreak in China: Summary of a report of 72314 cases from the Chinese Center for Disease Control and Prevention. JAMA. 2020; 323(13):123942. [DOI:10.1001/jama.2020.2648]

[2] Peeri NC, Shrestha N, Rahman MS, Zaki R, Tan Z, Bibi S, et al The SARS, MERS and novel Coronavirus (COVID-19) epidemics, the newest and biggest global health threats: What lessons have we learned? International Journal of Epidemiology. 2020; 49(3):717-26. [DOI:10.1093/ije/dyaa033]

[3] Sohrabi C, Alsafi Z, O'neill N, Khan M, Kerwan A, Al-Jabir A, et al. World Health Organization declares global emergency: A review of the 2019 novel Coronavirus (COVID-19). International Journal of Surgery. 2020; 76:71-6. [DOI:10.1016/j.ijsu.2020.02.034]

[4] Worldometer. COVID-19 coronavirus pandemic [Internet]. 2020 [Updated 2020 June 18]. Available from: https://www. worldometers.info/coronavirus/.

[5] Khafaie MA, Rahim F. Cross-country comparison of case fatality rates of COVID-19/SARS-COV-2. Osong Public Health and Research Perspectives. 2020; 11(2):74-80. [DOI:10.24171/j. phrp.2020.11.2.03]

[6] Zimmermann P, Curtis N. Coronavirus infections in children including COVID-19: An overview of the epidemiology, clinical features, diagnosis, treatment and prevention options in children. The Pediatric Infectious Disease Journal. 2020; 39(5): 355-68. [DOI:10.1097/INF.0000000000002660]
[7] Dong Y, Mo X, Hu Y, Qi X, Jiang F, Jiang Z, et al. Epidemiology of COVID-19 among children in China. Pediatrics. 2020; 145(6):e20200702. [DOI:10.1542/peds.2020-0702]

[8] Cheng Y, Luo R, Wang K, Zhang M, Wang Z, Dong L, et al Kidney disease is associated with in-hospital death of patients with COVID-19. MedRxiv. 2020; 1-21. [DOI:10.1101/2020.02.18. 20023242

[9] Driggin E, Madhavan MV, Bikdeli B, Chuich T, Laracy J, Biondi-Zoccai G, et al. Cardiovascular considerations for patients, health care workers, and health systems during the COVID-19 pandemic. Journal of the American College of Cardiology. 2020; 75(18):2352-71. [DOI:10.1016/j.jacc.2020.03.031]

[10] Prem K, Liu Y, Russell TW, Kucharski AJ, Eggo RM, Davies $\mathrm{N}$, et al. The effect of control strategies to reduce social mixing on outcomes of the COVID-19 epidemic in Wuhan, China: A modelling study. The Lancet Public Health. 2020; 5(5):e261-70. [DOI:10. 1101/2020.03.09.20033050

[11] World Health Organization. Considerations for quarantine of individuals in the context of containment for coronavirus disease (COVID-19): Interim guidance [Internet]. 2020 [Updated 2020 March 16]. Available from: https:/ /apps.who.int/iris/handle/10665/331497

[12] Ten Cate H. Thrombosis management in times of COVID-19 epidemy: A Dutch perspective. Thrombosis Journal. 2020; 18(7):1-3. [DOI:10.1186/s12959-020-00220-3Epub.]

[13] Abrigo MR, Uy J, Haw NJ, Ulep VG, Francisco-Abrigo K Projected disease transmission, health system requirements, and macroeconomic impacts of the Coronavirus Disease 2019 (COVID-19) in the Philippines. Quezon City: Philippine Institute for Development Studies; 2020. https://www.think-asia.org/ handle/11540/11871

[14] Cho H, Ippolito D, Yu YW. Contact tracing mobile apps for COVID-19: Privacy considerations and related trade-offs. arXiv:2003.11511. 2020. https:/ / arxiv.org/abs/2003.11511v2

[15] National Committee on COVID-19 Epidemiology. Daily situation report on coronavirus disease (COVID-19) in Iran March 13, 2020. Archives of Academic Emergency Medicine. 2020; 8(1):e23. [DOI:10.1001/jama.2020.4031]

[16] Grasselli G, Pesenti A, Cecconi M. Critical care utilization for the COVID-19 outbreak in Lombardy, Italy: Early experience and forecast during an emergency response. JAMA. 2020; 323(16):1545-6. [DOI:10.1001/jama.2020.4031]

[17] Liu C, Zhou Q, Li Y, Garner LV, Watkins SP, Carter LJ, et al. Research and development on therapeutic agents and vaccines for COVID-19 and related human coronavirus diseases. ACS Central Science. 2020; 6(3):315-31. [DOI:10.1001/jama.2020.4031]

[18] Hick JL, Biddinger PD. Novel coronavirus and old lessonspreparing the health system for the pandemic. The New England Journal of Medicine. 2020; 382(20):e55. [DOI:10.1056/NEJMp2005118]

[19] World Health Organization. Global learning laboratory for quality universal health coverage: Fourth global symposium on health systems research, 14 November 2016, Vancouver, Canada. Geneva: World Health Organization; 2017. https://apps.who. int/iris/handle/10665/254740

[20] World Health Organization. Coronavirus Disease (COVID-19): Situation report-209 [Internet]. 2020 [Updated 2020 August 16]. Available from: https://www.who.int/docs/ default-source/coronaviruse/ situation-reports/20200816covid-19-sitrep-209.pdf?sfvrsn=5dde1ca2 2 
[21] Robert Koch Institut. Kontaktpersonen-Nachverfolgung bei SARS-CoV-2-Infektionen (Follow-up of contact persons for SARS-CoV-2 infections [Internet]. 2021 [Updated 2021 July 14]. Available from: https://www.rki.de/DE/Content/ InfAZ/N/Neuartiges_Coronavirus/Kontaktperson/Management.html

[22] Sampson J. Linde to deliver oxygen to makeshift German hospital [Internet]. 2020 [Updated 2020 May 11]. Available from: https://www.gasworld.com/linde-to-deliver-oxygento-makeshift-german-hospital/2019065.article

[23] Salzmann M. German hospitals become COVID-19 hotspots for health care workers [Internet]. 2020 [Updated 2020 April 11]. Available from: https://www.wsws.org/en/articles/2020/04/11/hosp-a11.html.

[24] Thoms A. New EU and national export controls on face masks and medical protective equipment [Internet]. 2020 [Updated 2020 March 18]. Available from: https://www. bakermckenzie.com/en/insight/publications/2020/03/ new-eu-national-export-controls-medical-equipment.

[25] Bakir C. The Turkish state's responses to existential COVID-19 crisis. Policy and Society. 220; 39(3):424-441. [DOI:10.10 80/14494035.2020.1783786

[26] Demirbilek Y, Pehlivantürk G, Özgüler ZÖ, MEŞE EA. COVID-19 outbreak control, example of ministry of health of Turkey. Turkish Journal of Medical Sciences. 2020; 50(SI1):489-94. [DOI:10.3906/sag-2004-187]

[27] Sputniknews. [Erdoğan: Atatürk Havaliman ve Sancaktepe'de 1000 odal hastane kurulacak (Turkish)]. 2020 [Updated 2020 April 06]. Available from: https://tr.sputniknews.com/koronavirus-salgini / 202004061041767521-erdogan-ataturkhavaliman-ve-sancaktepe-1000-odali-hastane/.

[28] Seyahi E, Poyraz BC, Sut N, Akdogan S, Hamuryudan $\mathrm{V}$. The psychological state and changes in the routine of the patients with rheumatic diseases during the Coronavirus Disease (COVID-19) outbreak in Turkey: A web-based cross-sectional survey. Rheumatology International. 2020; 40(8):1229-38. [DOI:10.1007/s00296-020-04626-0]

[29] Zhang J, Savage VR. The geopolitical ramifications of COVID-19: The Taiwanese exception. Eurasian Geography and Economics. 2020; 61(4-5):464-81. [DOI:10.1080/15387216 .2020.1779773]

[30] Bostan S, Erdem R, Öztürk YE, Kılıç T, Yılmaz A. The effect of COVID-19 pandemic on the Turkish society. Electronic Journal of General Medicine. 2020; 17(6):em237. [DOI:10.29333/ejgm/7944]

[31] Tashiro A, Shaw R. COVID-19 Pandemic Response in Japan: What Is behind the initial flattening of the curve? Sustainability. 2020; 12(13):5250. [DOI:10.3390/su12135250]

[32] Park JM, Nakagawa I, Yamamitsu E. Running out of beds and gear, Tokyo medical staff say Japan's 'state of emergency' already here [Internet]. 2020 [Updated 2020 April 06]. Available from: https:/ / www.reuters.com/article/us-health-coronavirus-japan-hospitals-in-idUSKBN21O0K4

[33] Park JM, Saito M, Yamamitsu. On Japan's stretched front line, doctors and nurses DIY a coronavirus response [Internet]. 2020 [Updated 2020 April 28]. Available from: https:// www.reuters.com/article/us-health-coronavirus-japan-icuidUSKCN22A03L
[34] KPMG. Japan: Government and institution measures in response to COVID-19 [Internet]. 2020 [Updated 2020 December 02]. Available from: https://home.kpmg/xx/en/home/insights/2020/04/japan-government-and-institution-measuresin-response-to-covid.html

[35] Arai J. Japan doubles payments to hospitals for worst coronavirus cases [Internet]. 2020 [Updated April 18]. Available from: https://asia.nikkei.com/Business/Health-Care/Japan-doublespayments-to-hospitals-for-worst-coronavirus-cases

[36] Raoofi A, Takian A, Sari AA, Olyaeemanesh A, Haghighi H, Aarabi M. COVID-19 pandemic and comparative health policy learning in Iran. Archives of Iranian Medicine. 2020; 23(4):220-34. [DOI:10.34172/aim.2020.02]

[37] Kim SW, Lee KS, Kim K, Lee JJ, Kim JY; Daegu Medical Association. A brief telephone severity scoring system and therapeutic living centers solved acute hospital-bed shortage during the COVID-19 outbreak in Daegu, Korea. Journal of Korean Medical Science. 2020; 35(15):e152. [DOI:10.3346/jkms.2020.35.e152] [PMID] [PMCID]

[38] Yum HK. Suggestions to prepare for the second epidemic of COVID-19 in Korea. Journal of Korean Medical Science. 2020; 35(19):e191. [DOI:10.3346/jkms.2020.35.e191] [PMID] [PMCID]

[39] Yoon D. How South Korea solved its acute hospital-bed shortage. Wall Street Journal. 2020. [Published Online]. https:/ / www. wsj.com/articles/how-south-korea-solved-its-acute-hospitalbed-shortage-11584874801

[40] Moon MJ. Fighting against COVID-19 with agility, transparency, and participation: Wicked policy problems and new governance challenges. Public Administration Review. 2020; 80(4):651-6. [DOI:10.1111/puar.13214] [PMID] [PMCID]

[41] Her M. Repurposing and reshaping of hospitals during the COVID-19 outbreak in South Korea. One Health. 2020; 10:100137. [DOI:10.1016/j.onehlt.2020.100137] [PMID] [PMCID]

[42] Wu F, Zhao S, Yu B, Chen YM, Wang W, Song ZG, et al. A new coronavirus associated with human respiratory disease in China Nature. 2020; 579(7798):265-9. [DOI:10.1038/s41586-020-2008-3] [PMID] [PMCID]

[43] Jobst N. (May 29, 2020) Number of face masks produced daily in South Korea during the novel coronavirus (COVID-19) outbreak as of March 8, 2020, by destination [Internet]. 2020 [Updated 2021 March 5]. Available from: https://www.statista.com/ statistics/1102784/south-korea-daily-supply-of-face-masksduring-coronavirus-outbreak-by-destination/

[44] Chung D, Soh H. Korea's response to COVID-19: Early lessons in tackling the pandemic [Internet]. 2020 [Updated 2020 March 23]. Available from: https:/ / blogs.worldbank.org/eastasiapacific/koreas-response-covid-19-early-lessons-tackling-pandemic.

[45] Huh S. How to train health personnel to protect themselves from SARS-CoV-2 (novel coronavirus) infection when caring for a patient or suspected case. Journal of Educational Evaluation for Health Professions. 2020; 17:10. [DOI:10.3352/jeehp.2020.17.10] [PMID] [PMCID]

[46] Signorelli C, Odone A, Gianfredi V, Bossi E, Bucci D, Oradini-Alacreu A, et al. The spread of COVID-19 in six western metropolitan regions: A false myth on the excess of mortality in Lombardy and the defense of the city of Milan. Acta Biomedica: Atenei Parmensis. 2020; 91(2):23-30. [DOI:10.3352/ jeehp.2020.17.10] [PMID] [PMCID] 
[47] Liwanag V. [COVID-19] fieraMilano city repurposed into a temporary hospital in 10 days [Internet]. 2020 [Updated 2020 April 02]. Available from: http://emag.archiexpo.com/covid-19-fieramilanocity-repurposed-into-a-temporary-hospitalin-10-days/.

[48] Vecchi V, Cusumano N, Boyer EJ. Medical supply acquisition in Italy and the United States in the Era of COVID-19: The case for strategic procurement and public-private partnerships. The American Review of Public Administration. 2020; 50(6-7):642-9. [DOI:10.1177/0275074020942061]

[49] Mingardi A. Italy's covid price-control fiasco [Internet]. 2020 [Updated 2020 May 18]. Available from: https:// www.wsj.com/articles/italys-covid-price-control-fiasco-11589842827.

[50] Palaniappan A, Dave U, Gosine B. Comparing South Korea and Italy's healthcare systems and initiatives to combat COVID-19. Revista Panamericana de Salud Pública. 2020; 44:e53. [DOI:10.26633/RPSP.2020.53] [PMID] [PMCID]

[51] Kılınçel Ş, Kılınçel O, Muratdağı G, Aydın A, Usta MB. Factors affecting the anxiety levels of adolescents in home-quarantine during COVID-19 pandemic in Turkey. Asia-Pacific Psychiatry. 2020; 13(2):e12406. [DOI:10.1111/appy.12406] [PMID] [PMCID]

[52] Kluge S, Janssens U, Welte T, Weber-Carstens S, Marx G, Karagiannidis C. German recommendations for critically ill patients with Covid-19. Medizinische Klinik, Intensivmedizin und Notfallmedizin. 2020; 115(Suppl 3):111-4. [DOI:10.1007/ s00063-020-00689-w] [PMID] [PMCID]

[53] Nicola M, Alsafi Z, Sohrabi C, Kerwan A, Al-Jabir A, Iosifidis $\mathrm{C}$, et al. The socio-economic implications of the coronavirus pandemic (COVID-19): A review. International Journal of Surgery. 2020; 78:185-93. [DOI:10.1016/j.ijsu.2020.04.018]

[54] Meier K, Glatz T, Guijt MC, Piccininni M, Van Der Meulen M, Atmar K, et al. Public perspectives on protective measures during the COVID-19 pandemic in the Netherlands, Germany and Italy: A survey study. PloS One. 2020; 15(8):e0236917. [DOI:10.1371/journal.pone.0236917] [PMID] [PMCID]

[55] Klompas M. Coronavirus Disease 2019 (COVID-19): Protecting hospitals from the invisible. Annals of Internal Medicine. 2020; 172(9):619-20. [DOI:10.7326/M20-0751] [PMID] [PMCID]

[56] Balduzzi A, Brivio E, Rovelli A, Rizzari C, Gasperini S, Melzi ML, et al. Lessons after the early management of the COVID-19 outbreak in a pediatric transplant and hematooncology center embedded within a COVID-19 dedicated hospital in Lombardia, Italy. Estote parati. Bone Marrow Transplantation. 2020; 55(10):1900-05. [DOI:10.1038/s41409020-0895-4] [PMID] [PMCID]

[57] Adams JG, Walls RM. Supporting the health care workforce during the COVID-19 global epidemic. JAMA. 2020; 323(15):1439-40. [DOI:10.1001/jama.2020.3972] [PMID]

[58] Mavioğlu HL, Ünal EU, Aşkın G, Küçüker ŞA, Özatik MA. Perioperative planning for cardiovascular operations in the COVID-19 pandemic. Türk Göğüs Kalp Damar Cerrahisi Dergisi. 2020; 28(2):236-43. [DOI:10.5606/tgkdc.dergisi.2020.09294] [PMID] [PMCID]

[59] Alhas AM. Turkey's healthcare system vigilant against COVID-19 [Internet]. 2020 [Updated 2020 April 05]. Availble from: https://www.aa.com.tr/en/health/turkey-s-healthcare-system-vigilant-against-covid-19/1828167\#
[60] Erdeve Ö, Çetinkaya M, Baş AY, Narlı N, Duman N, Vural M, et al. The Turkish Neonatal Society proposal for the management of COVID-19 in the neonatal intensive care unit. Turkish Archives of Pediatrics. 2020; 55(2):86-92. [DOI:10.5606/tgkdc.dergisi.2020.09294] [PMID] [PMCID]

[61] Ersoy A. The frontline of the COVID-19 pandemic: Healthcare workers. Turkish Journal of Internal Medicine. 2020; 2(2):31-2. [DOI:10.46310/tjim.726917]

[62] Colombo C, Burgel PR, Gartner S, van KoningsbruggenRietschel S, Naehrlich L, Sermet-Gaudelus I, et al. Impact of COVID-19 on people with cystic fibrosis. The Lancet Respiratory Medicine. 2020; 8(5):e35-6. [DOI:10.1016/S22132600(20)30177-6] [PMID] [PMCID]

[63] Barret JP, Chong SJ, Depetris N, Fisher MD, Luo G, Moiemen $\mathrm{N}$, et al. Burn center function during the COVID-19 pandemic: An international multi-center report of strategy and experience. Burns. 2020; 46(5):1021-35. [DOI:10.1016/j. burns.2020.04.003Epub.] [PMID] [PMCID]

[64] Chughtai AA, Seale H, Islam MS, Owais M, Macintyre CR. Policies on the use of respiratory protection for hospital health workers to protect from Coronavirus Disease (COVID-19). International Journal of Nursing Studies. 2020; 105:103567. [DOI:10.1016/j.ijnurstu.2020.103567] [PMID] [PMCID]

[65] Saito M, Miyazaki A. Peeling back the hospital curtain: One Japanese hospital's fight against COVID-19 [Internet]. 2020 [Updated 2020 July 1]. Availble from: https://www.japantimes.co.jp/news/2020/07/01/national/hospitals-reopenaftermath-coronavirus/

[66] Ropeik D. Poor risk communication in Japan is making the risk much worse [Internet]. 2020 [Updated 2020 March 21]. Availble from: https://blogs.scientificamerican.com/guestblog/poor-risk-communication-in-japan-is-making-the-riskmuch-worse/

[67] Kadoya Y, Zen K, Wakana N, Yanishi K, Senoo K, Nakanishi N, et al. Knowledge, perception, and level of confidence regarding COVID-19 care among healthcare workers involved in cardiovascular medicine: A web-based cross-sectional survey in Japan. Journal of Cardiology. 2021; 77(3):239-44. [DOI:10.1016/j.jjcc.2020.07.029] [PMID] [PMCID]

[68] Ministry of Health and Medical Education. Social distance and general environmental and occupational health requirements in hospitals, health care centers. Tehran: Ministry of Health and Medical Education; 2020. https://iums.ac.ir/ files/pbr/files/book1koovid19.pdf

[69] Alesina A, Giavazzi F. The EU must support the member at the centre of the COVID-19 crisis. Mitigating the COVID economic crisis: Act fast and do whatever it takes. Washington, D.C.: CEPR Press; 2020. https://www.google.com/ books/edition/Mitigating_the_COVID_Economic_Crisis/ fgPCZQEACAAJ?hl=en

[70] Lee D, Lee J. Testing on the move: South Korea's rapid response to the COVID-19 pandemic. Transportation Research Interdisciplinary Perspectives. 2020; 5:100111. [DOI:10.1016/j. trip.2020.100111] [PMID] [PMCID]

[71] Park J. Changes in subway ridership in response to COVID-19 in Seoul, South Korea: Implications for social distancing. Cureus. 2020; 12(4):e7668. [DOI:10.7759/cureus.7668] [PMID] [PMCID] 
[72] Chen X, Wu YT. Weathering COVID-19: Lessons from Wuhan and Milan for urban governance and sustainability. European Financial Review. 2020; 16-27. https:// digitalrepository.trincoll.edu/cgi/viewcontent. cgi? article $=1245 \&$ context $=$ facpub

[73] Giuffrida A. 'This Is not a film': Italian mayors rage at virus lockdown dodgers. The Guardian. 2020 [Published Online] https:/ / www.theguardian.com/world/2020/mar/23/thisis-not-a-film-italian-mayors-rage-coronavirus-lockdowndodgers

[74] Varrella S. How would you rate the Italian government in how it is communicating information about the coronavirus outbreak? [Internet]. 2020 [Updated 2020 Augest 17]. Available from: https://www.statista.com/statistics/1106755/ opinions-on-italian-government-s-information-on-coronavirus/

[75] Torri E, Sbrogiò LG, Di Rosa E, Cinquetti S, Francia F, Ferro A. Italian public health response to the COVID-19 pandemic: case report from the field, insights and challenges for the department of prevention. International Journal of Environmental Research and Public Health. 2020; 17(10):3666. [DOI:10.3390/ijerph17103666] [PMID] [PMCID]

[76] Jee Y. WHO International Health Regulations Emergency Committee for the COVID-19 outbreak. Epidemiology and Health. 2020; 42:e2020013. [DOI:10.4178/epih.e2020013] [PMID] [PMCID]

[77] Jean-Gilles L, Nicoll A, Pentinnen P, Brown C. Key changes to pandemic plans by Member States of the WHO European Region based on lessons learnt from the 2009 pandemic. Geneva: World Health Organization; 2012. https:/ / www.cabdirect.org/globalhealth/abstract/20123334410

[78] Ungchusak K, Sawanpanyalert P, Hanchoworakul W, Sawanpanyalert N, Maloney SA, Brown RC, et al. Lessons learned from influenza A (H1N1) pdm09 pandemic response in Thailand. Emerging Infectious Diseases. 2012; 18(7):1058-64. [DOI:10.3201/eid1807.110976] [PMID] [PMCID]

[79] Kraemer MU, Yang CH, Gutierrez B, Wu CH, Klein B, Pigott $\mathrm{DM}$, et al. The effect of human mobility and control measures on the COVID-19 epidemic in China. Science. 2020; 368(6490):493-7. [DOI:10.1126/science.abb4218] [PMID] [PMCID]

[80] Kwon K T, Ko JH, Shin H, Sung M, Kim JY. Drive-through screening center for COVID-19: A safe and efficient screening system against massive community outbreak. Journal of Korean Medical Science. 2020; 35(11):e123. [DOI:10.3346/ jkms.2020.35.e123] [PMID] [PMCID]

[81] Langabeer JR 2nd, Gonzalez M, Alqusairi D, ChampagneLangabeer T, Jackson A, Mikhail J, et al. Telehealth-enabled emergency medical services program reduces ambulance transport to urban emergency departments. Western Journal of Emergency Medicine. 2016; 17(6):713-20. [DOI:10.5811/ westjem.2016.8.30660] [PMID] [PMCID]

[82] Hollander JE, Carr BG. Virtually perfect? Telemedicine for COVID-19. New England Journal of Medicine. 2020; 382(18): 1679-81. [DOI:10.1056/NEJMp2003539] [PMID]

[83] Bozzalla Cassione E, Zanframundo G, Biglia A, Codullo V, Montecucco C, Cavagna L. COVID-19 infection in a northern-Italian cohort of systemic lupus erythematosus assessed by telemedicine. Annals of the Rheumatic Diseases. 2020 79(10):1382-3. [DOI:10.1056/NEJMp2003539] [PMID]
[84] World Health Organization. World patient safety day [Internet]. 2020 [Updated 2020 September 17]. Availble from: https://www.who.int/campaigns/world-patient-safetyday $/ 2020$

[85] Ranney ML, Griffeth V, Jha AK. Critical supply shortagesthe need for ventilators and personal protective equipment during the Covid-19 pandemic. New England Journal of Medicine. 2020; 382(18):e41. [DOI:10.1056/NEJMp2006141] [PMID]

[86] Ahmed T. 'Survival'as a societal value. International Journal of Research and Analytical Reviews. 2020; 7(2):592-9. https:/ / www.researchgate.net/profile/Tanzeem-Ahmed/publicatio n/3444774499_Survival'_as_a_Societal_Value_Biopolitics_in Times_of_Corona/links/5f7b375a458515b7cf67c75a/Survival-as-a-Societal-Value-Biopolitics-in-Times-of-Corona.pdf

[87] Horowitz J. How Italy turned around its Coronavirus calamity [Internet]. 2020 [ Updated 2020 July 31]. Availble from: https://www.nytimes.com/2020/07/31/world/europe/ italy-coronavirus-reopening.html

[88] Chopra V, Toner E, Waldhorn R, Washer L. How should US hospitals prepare for Coronavirus Disease 2019 (COVID-19)? Annals of Internal Medicine. 2020; 172(9):621-2. [DOI:10.7326/M20-0907] [PMID] [PMCID]

[89] Leal Filho W, Brandli LL, Lange Salvia A, Rayman-Bacchus L, Platje J. COVID-19 and the UN sustainable development goals: Threat to solidarity or an opportunity? Sustainability. 2020; 12(13):5343. [DOI:10.3390/su12135343]

[90] Li X, Yu H, Bian G, Hu Z, Liu X, Zhou Q, et al. Prevalence, risk factors, and clinical correlates of insomnia in volunteer and at home medical staff during the COVID-19. Brain, Behavior, and Immunity. 2020; 87:140-1. [DOI:10.1016/j. bbi.2020.05.008] [PMID] [PMCID] 